\title{
Parametric, Non-Parametric and Multivariate Analysis of Capital Structure During the Financial Crises in Jordanian Banks
}

\author{
Ahmad Y. Khasawneh*
}

Department of Finance, Prince Sultan University, KSA

\begin{abstract}
Motivations: This research seeks to analyze the determinants of capital structure of the banking sector in Jordan taking into consideration bank business model (Islamic versus Commercial bank). The research also sheds light on the financial crises of 2007/2008 and its impact on the financing decision in the banking sector.
\end{abstract}

Novelty: Although the topic of capital structure's determinants is well studied in non-financial firms, very few studies considered the financial firms, namely banks. Since the nature of operations and capital components for banks are totally different this research comes to fill the gap in the banking literature.

Methodology and Methods: The study uses multivariate regression techniques of panel data besides the parametric and non-parametric analysis. Three measurements of capital structure are considered: leverage ratio, long term debt ratio and short-term debt ratio, the explanatory variables are included in two sets, bank specific characteristics and economic characteristics.

Data and Empirical Analysis: Balanced panel data set was formed for 27 Jordanian banks during the period of 20032015. Empirically, the findings suggest a variation of capital structure determinants based on the variable of measurement. However, the analysis confirms that bank's profitability and bank's risk are major components of the capital structure decision regardless of its measurement variable. In addition to these two variables, liquidity, growth and taxes are important variable in the short-term debt financing, and retained earnings is important to the long-term financing. Empirically proven that Jordanian banks' capital structure decision is affected by the global financial crisis $2007 / 2008$ and by bank type. Jordanian banks might differ in size, but this doesn't affect their policies toward the capital structure. The empirical results are consistent with the pecking order theory that profitable firms prefer to use more of their internal sources of funds rather than debt financing.

Policy Implications: Due to the importance of the capital structure decision for banks and non-banks firms and based on our finding, the policy makers in Jordan and may in other similar countries should pay attention to capital requirement regulations as the determinants of leverage among banks are different based on the business model whether commercial or Islamic.

Keywords: Banks Leverage, Financial Crises, Jordanian Banks, Islamic Versus Commercial banks, Parametric Analysis, Non - Parametric Analysis.

\section{INTRODUCTION}

A debate regarding the optimal capital structure a firm should adopt started in 1950s when Modigliani and miller introduced their seminal work in 1958 and the debate continues until now, several theories in this regard were emerged. Modigliani and Miller (1958) investigate the optimal capital structure of a firm under the perfect market assumption. Modigliani and Miller in their second work in 1963 introduce a market friction assumption by adding taxes, they give preference to the debt financing. Jensen and Meckling 1976 and Jensen 1986 introduced the agency cost theory, their point of view suggests that using debt financing to a certain level will be better than equity financing. Myers (1984) discusses the trade off between tax shield of debt financing and the cost of financial distress. Tradeoff theory suggest that the marginal benefit of further debt decreases as debt increases, while the

*Address correspondence to these authors at the Department of Finance, Prince Sultan University, KSA; Tel: 0096654526629; Fax: 00966114548317; E-mail: akhasawneh@psu.edu.sa

JEL: G01, G21, G32, N25. marginal cost of further debt increases as debt increases. Fama and French (2002) examined the trade-off theory and conclude that firms will build their decision of the capital decision based on the trade-off between the benefits of debt financing and the cost of higher debt risk level. Myers and Majluf (1984) introduce the pecking order theory which suggests that firms have a particular preference order for capital structure. Pecking order theory suggest that profitable firms uses less on debt financing since more internal funds are available, while less profitable firms use more debt financing and more external funds in general.

The three capital structure theories were competing in the existing to study the factors to determine the capital structure. However, most of these studies are directed to non-financial firms and less studies considered financial companies. Berger and Szego (1995) study the role of capital structure and its importance in financial institutions; they declare that the requirements of market capital increase banks value. They find that investors prefer equity financing as it raises the rate of return, while owners prefer debt financing to get benefit from tax shield. 
Banking sector is a very important sector in Jordan in terms of its contribution to the GDP, where the consolidated balances of licensed banks showed total assets of 42.8 billion Jordanian Dinars in 2013 which makes up $177 \%$ of GDP in Jordan. Moreover, the traded shares of financial sector were $69.4 \%$ of the total number of traded shares in Amman stock exchange (Central Bank of Jordan annual report, 2013). Banking sector is very important to support the development process in any country in terms of being a source of credit to finance important project (Ternovskaya and Alexander 2018)

Islamic banking has grown rapidly in all parts of the world achieving a universal acceptance, besides being a viable alternative system, which have many privileges to offer, especially, in the emerging countries (Sufian and Noor 2009). Throughout the recent global financial crisis, the Islamic banking in the Middle East and North Africa (MENA) region has demonstrated resilience compared to Commercial banks (Hasan and Dridi 2010). There are three factors supporting the Islamic banks stability during the early crisis according to (Syed 2011); Islamic banks financing activities are more tied to real economic activities compared to commercial banks, Islamic banks avoid direct exposure to the financial derivative products, and Islamic banks have maintained a larger proportion of their assets in liquid compared with Commercial banks.

This research aims to analyze the determinants of capital structure of the banking sector in Jordan during the period between 2003 and 2015. We also examine wither the determinants of capital structure differ according to bank's type, Larionova et al. (2018) suggest that leverage levels must be based on the differences between banks based on the various business model. Additionally, the research tries to distinguish whether the Jordanian banks adjust their behavior regarding capital structure because of the financial crisis of 2007/2008.

The next section introduces a review to the existing literature, hypotheses, methodologies and samples of analysis are introduced next. Section four describes sample characteristics, data sources and summary Statistics. Empirical results presented next. Finally, conclusions and recommendations are presented.

\section{LITERATURE REVIEW}

The choice and determinants of capital structure has been quite a focused field in corporate finance during the last decades and numerous studies have been conducted trying to explain firms' capital structure. In this section we survey the most recent studies that are concerned in the determinants of capital structure.

Using cross-sectional tests Wald (1999) finds that profitability is the major determinants of debt ratio in the United States, Japan, United Kingdom, France, and Germany. Although mean leverage and other firm's factors appear to be similar across countries, some significant differences hold across countries, such as the correlation between long-term debt/asset ratios and the firms' riskiness, profitability, size, and growth. These differences can be referred to the differences in tax policies and agency problems, including differences in bankruptcy costs, information asymmetries, and shareholder/creditor conflicts. The findings of this study suggest links between varying choices in capital structure across countries with legal and institutional differences.

Yu (2000) examines the determinants of the capital ratio of Taiwanese banks. Employing time-series crosssection regression on a sample of 243 domestic Taiwanese banks during the period from 1986 to 1996. $\mathrm{He}$ investigates the relationship between bank's equity ratio and profitability, liquidity, bank size, money market funds and intermediation spreads. The author shows that capital structure is determined by Banks' size, liquidity and profitability. Moreover, the results suggest that capital ratio in large banks is much lower than in small banks, and there is positive and significant relationship between leverage ratio and liquidity ratio for small banks, while it is negative and significant for medium size banks.

A study by Omet and Nobanee (2001) analyzes the capital structure of the listed industrial companies in Jordan in the period between 1978 and 1998. They suggest that leverage is significantly determined by company size, retained earnings to total assets ratio, fixed assets ratio and total assets.

A study by Siam et al. (2005) analyzes the capital structure of banking sector in Jordan in the period from 1992 to 2001, using firm-level panel data. They conclude that capital structure measured by leverage ratio determined by the size of the bank, retained earnings to total assets ratio, liquidity ratio and the long and short - term debt. Their result also suggest that bank's capital structure is positively related to bank's age and the total assets associated with the retained 
earnings ratio, while capital structure is negatively related to the liquidity ratio associated with the long and short-term debt.

Amidu (2007) studies the determinants of capital structure of banks in Ghana using panel regression model. He finds profitability, asset structure, size, growth and corporate tax are among the significant determinants of banks' capital structure. Moreover, the results conclude that Ghanaian Banks depends on debt heavily, especially the short-term.

Mouamer (2011) examines the relationship between capital structure and debt lifetime among listed companies in Palestine stock market. Employing panel data regression model on a sample includes 15 nonfinancial (service, industrial, trade and agriculture) firms that qualified to be Included in the study sample during the period between 2000 to 2004. The model demonstrates that return of assets, liquidity, size, assets tangibility, growth and age considered as a main determinant. The empirical results show no significant difference in the use of debt, neither total, short term nor long term debt among companies in the four sectors. Moreover, the correlation analysis shows that there is a significant positive relationship between total debt and assets tangibility. And there is no significant relationship between long term debt nor short term debt and age, growth, liquidity, tangibility, and size on the other hand.

Fosberg (2012) finds a considerable impact of financial crisis on the financial institutions as it affects the debt ratio of the firm. Amjad, Bilal and Tufail (2013) examine the determinants of capital structure in banking sector of Pakistan. Employing panel data model regression on a sample contains 26 banks during the period from 2007 to 2011 . They find that bank's size and liquidity positively affect leverage, but tangibility, profitability and growth opportunities have negative influence on leverage.

Ukaegbu and Oino (2014) analyze the differences in capital structure determinants between financial and non-financial firms in Nigeria. Employing pooled ordinary least square, the random effects and fixed effects regressions on a sample contained all banks and non-financial firms that are listed on Nigeria stock exchange. They suggest considerable differences between the two types, where banks tend to be more leveraged when they are more profitable while nonfinancial firms tend to be less leveraged when they are profitable.
Chen et al. (2014) investigate the determinants of capital structure of the non-financial firms listed on the Chinese stock exchanges. Employing ordinary least squares (OLS) and White robust correction estimator on an across-section sample of 1,481 non-financial firms listed on the Chinese stock exchanges in 2011. Among their study they find that firm size, profitability, growth opportunity, intangibility and business risk have an impact on the leverage ratio which used as proxy to the capital structure, while tax has a little impact on capital structure.

Alipour et al. (2015) investigate the determinants of capital structure of non-financial firms in Iran. Employing panel data model on a sample contained all firms listed in Tehran Stock exchange during the period from 2003 to 2007 . To investigate factors affecting the debt financing as a proxy for corporate capital structure. They find that firm's size, financial flexibility, asset structure, profitability, liquidity, growth, risk and state ownership affect all measures of capital structure of Iranian corporations.

This research main objective is to analyze the determinants of capital structure (leverage) of the banking sector in Jordan during the time between 2003 and 2015. Additionally, we aim to differentiate the investigations according to the bank type, commercial and Islamic banks. Moreover, we are also interested to check the impact of 2007/2008 financial crisis on Jordanian banks main decisions, such as capital structure.

\section{METHODOLOGY}

To examine our research questions, we employ three types of analyses: multivariate regression analysis, parametric analysis and non - parametric analysis. Following is a detailed explanation of each of these methods.

\section{Multivariate Regression Analysis}

The method of regression analysis provides two level tests, one examines whether the relationship exists and the second examines the quantitative and the directional relationship between the variables of interests. A multivariate regression model is constructed to examine the determinants of capital structure in the banking industry in Jordan. The model contains banks specific variables, macroeconomics variables such as tax rate, in addition to type dummy and financial crisis year dummy. We also outline the 
methods of measurement for bank specific characteristics and macroeconomic factors.

\section{Modeling the Determinants of Capital Structure}

Examining the determinants of Jordanian banks' capital structure, an empirical model has been set and the explanatory variables have been carefully selected according to the previous literature and how far data been available for measurement purposes, along with the specific objectives of this study.

Since the study requires analyzing a sample contained data for various factors and various banks through several time periods, we follow Ooi (1999) and Amidu (2007) in constructing panel data model to regress bank's capital structure ratios against the explanatory variables, panel data model helps to facilitate identification of effects that are simply not detectable in pure cross-sections or pure time-series studies.

Following (Remmers et al. 1974; Cassar and Holmes 2003; Amidu, 2007 and Ezeoha 2008) we use leverage ratio (total), short-term leverage ratio and long-term leverage ratio as the dependent variable to proxy for capital structure in our model. In the other hand, our models contain a set of explanatory variables at both levels, bank specific and macroeconomic.

Our study forms the following model of capital structure:

Leverage $_{i t}=\delta_{0}+\delta_{1}$ perf $_{i t}+\delta_{2}$ Reta $_{i t}+\delta_{3}$ Liq $_{i t}+\delta_{4}$ Growth $_{i t}$

$+\delta_{5}$ Tang $_{i t}+\delta_{6}$ Risk $_{i t}+\delta_{7}$ Tax $_{i t}+\delta_{8}$ Size $_{i t}$

$+\delta_{j}$ Crisis Dummy $_{j}+\varepsilon_{i t}$

$S T D T A_{i t}=\delta_{0}+\delta_{1}$ perf $_{i t}+\delta_{2} \operatorname{Reta}_{i t}+\delta_{3} \operatorname{Liq}_{i t}+\delta_{4}$ Growth $_{i t}$

$+\delta_{5}$ Tang $_{i t}+\delta_{6}$ Risk $_{i t}+\delta_{7}$ Tax $_{i t}+\delta_{8}$ Size $_{i t}$

$+\delta_{j}$ Crisis Dummy $_{j}+\varepsilon_{i t}$

$\operatorname{LTDTA}_{i t}=\delta_{0}+\delta_{1} \operatorname{perf}_{i t}+\delta_{2} \operatorname{Reta}_{i t}+\delta_{3} \operatorname{Liq}_{i t}+\delta_{4}$ Growth $_{i t}$

$+\delta_{5}$ Tang $_{i t}+\delta_{6}$ Risk $_{i t}+\delta_{7}$ Tax $_{i t}+\delta_{8}$ Size $_{i t}$

$+\delta_{j}$ Crisis Dummy $_{j}+\varepsilon_{i t}$

According to the previous literature, capital structure can be defined and proxied in several measures. Modigliani and Miller theory defines the capital structure in terms of market value of debt and equity, but (Myers 1977) asserts that financial market fluctuations value measures are difficult and unreliable. Some empirical studies employ market value measures as (Baker and Wurgler 2002), while others use both market value and accounting book value measures (Bennett and Donnelly 1993; Booth et al. 2001). Other studies use single leverage ratio, either long-term or total leverage ratio (Bennett and Donnelly 1993; Bradley et al. 1984; DeWenter and Malatesta 2001 and Chen et al. 2014). Also, many studies use multiple leverage ratios (i.e. total debt, short-term debt, and long-term debt) to depict a more complete picture of financing decision (Titman and Wessels 1988; Rajan and Zingales 1995; Frank and Vidhan 2009 and Amidu 2007).

In our study, following (Remmers et al. 1974; Cassar and Holmes 2003 and Amidu 2007) we use leverage ratio measured by short-term leverage ratio and long-term leverage ratio to be the dependent variable to proxy for capital structure.

In equation (1), we use bank's leverage ratio (Leverage) against the explanatory variables. Based on our study's feature and the models suggested by (Ooi 1999; Siam et al. 2005; Delcoure 2007 and Amidu 2007), the dependent variable (Leverage) is measured as the ratio of total liabilities to the total assets using the book value for both (Harris and Raviv 1991; Rajan and Zingales 1995; Bevan and Danbolt 2000; Omet and Nobanee 2001; Buferna, et al. 2005 and Chen et al. 2014).

In equation (2), we use bank's short term leverage ratio (STDTA) against the explanatory variables. STDTA is defined as the portion of bank's total debt repayable within one year (i.e., deposits and current account) measured in the ratio of current liabilities to the total assets using the book value for both as (Remmers et al. 1974; Cassar and Holmes 2003 and Amidu 2007).

In equation (3), we use the bank's long term leverage ratio (LTDTA) against the explanatory variables. The dependent variable is defined as the portion of bank's total debt repayable within more than one year measured in the ratio of non-current liabilities to the total assets using the book value for both as (Remmers et al. 1974; Harris and Raviv 1991; Rajan and Zingales 1995; Huang and Song 2002; Antonion et al. 2002; Cassar and Holmes 2003; Buferna et al. 2005 and Amidu 2007).

We set several explanatory variables to be included in our three models, the first group includes bank specific characteristics and the second group macroeconomics variables in addition to a dummy 
variable to account for the financial crises. Below is an explanation to the reasoning of including each one of the variables, its expected effect and its theoretical roots based on the existing literature.

Bank's Profitability (Prof), the value of earnings before interest and tax over the book value of total assets is used a proxy for bank's performance (Ooi 1999; Amidu 2007 and Chen et al. 2014), according to the pecking order model there is a negative relationship between profitability and leverage, since firms with high profit are expected to make use of less debt for their investment activities that is supported by many empirical studies (e.g. Titman and Wessels 1988; Myers 2001; Fama and French 2002; Chen and Strange 2005; Amidu 2007 and Chen et al. 2014) We use ratio of pretax income on total assets (ROA) as a proxy for bank's performance.

The second variable we include is the retained Earnings to Total Assets Ratio (Reta), which measures cumulative profitability over time as a proportion of total assets; this accounts for how much firms have financed their assets through retention of profits. The higher bank's retained earnings will enhance bank's ability of financing assets out of its own sources and repaying liabilities according to (Siam et al. 2005). Additionally, the higher bank's retained earnings the higher ability to get levered, thereby yielding positive impacts through tax shield, (Berger and Szego 1995 and Siam et al. 2005).

Liquidity ratio (LIQ) is measured by the current ratio that is calculated as (Current Assets to Current Liabilities) (Graham 2000; Ozkan 2001; Antoniou et al. 2002; Siam et al. 2005; Sinan 2011; Sheikh and Wang 2011; and Danso and Adomako 2014). Current ratio is a financial ratio measures whether a firm has enough resources to pay its debts over the next fiscal year or not. High current ratio means that the company is more likely to meet its liabilities which fall due in the next fiscal year through effective management of working capital. A negative relationship is expected between the liquidity and bank's leverage (Ozkan 2001; Antoniou et al. 2002 and Siam et al. 2005).

Sales Growth rate (GROWTH) is used in our study as a proxy for bank's growth rate as firms with high growth rate need to look for external funds to finance their growth, (Amidu 2007). According to the pecking order arguments, growing firms have greater demand on their internally generated fund. A set of empirical studies find that future growth is positively related to leverage (Michaelas et al. 1999). Additionally, (Amidu 2007) shows a positive relationship between growth and leverage moreover he argue that banks with a relatively high growth rate will tend to look at short-term less secured debt first then to longer-term more secured debt to finance their growth. While (Chittenden et al. 1996; and Jordan et al. 1998) find mixed evidence about the relationship between firm's growth and firm's leverage.

Assets tangibility (TANG) measured as the ratio of fixed assets to total assets (Deesomsak et al. 2004 and Danso and Adomako 2014), it's kind of assets structure measurements which shows how much of the firm's assets are tangible that's would indicates the firm's liquidation value (Amidu 2007). The empirical results are mixed between positive and negative relationship between assets tangibility and leverage. The first group of empirical studies comes consistent with the argument of (Myers 1977) that tangible assets support higher debt level. Harris and Raviv 1991; Rajan and Zingales 1995; Bevan and Danbolt 2000; Omet and Nobanee 2001; and Buferna et al. 2005 suggest that tangible assets are positively correlated with leverage ratio, because firms may use fixed assets as collateral to issue more debt to take advantage of this opportunity. Moreover (Amidu 2007) found leverage of banks is negatively related to operating assets which measured by fixed to total assets in the Ghanaian banks.

Banks' risk (RISK) is measured by variation in profit. It is one of the common determinants of capital structure that have been adopted by scholars as (Amidu 2007; Ooi 1999; and Chen et al. 2014). In our study we use the standard deviation of the return on assets using three-year overlapping method as a proxy for the business risk following (Danso and Adomako 2014). According to the trade-off theory; firms with higher risk expected to have lower leverage ratio since the volatility of profit leads to higher bankruptcy costs. Unlike, the pecking order theory predicts a higher leverage ratio for firms with higher risk as these firms tend to borrow more due to adverse selection effect. Following literature (Bradley et al. 1984; Titman and Wessels 1988; Booth et al. 2001; Chen et al. 2014), this study tests for whether the trade-off theory better explains the relationship between risk and debt ratio. While Chen et al. (2014) finds business risk increases the level of debt financing; other empirical evidence suggests that there is a negative relationship between risk and leverage of small firms (Ooi 1999 and Titman and Wessels 1988). However others such as (Amidu 
2007) suggest that there is no support of risk influencing the level of leverage of banks in Ghana.

Effective tax rate (TAX), following previous studies the tax policy is a very important determinant of capital structure (Ooi 1999; and Alipour 2014). The effective tax rate is calculated as the ratio of paid taxes to earnings before taxes, while the paid taxes are calculated by subtracting earnings after taxes from earnings before taxes. Amidu (2007) used the ratio of pre-tax profit to determine factors affect capital structure decision and found a positive relationship between the paid tax and leverage in Ghana's banks. In this study we follow Chen and Strange (2005) and Chen et al. (2014) who use Tax shield proxied by the ratio of corporate income tax to operating profit following. In this study we expect a positive relationship between the effective tax rate and leverage.

Bank size (SIZE), we use the natural logarithm of Total Assets as the proxy for the size of bank to address the possible non-linearity of the relationship between bank size and leverage as in (Titman \& Wessels 1988; Ooi 1999; Huang and Song 2002 and Antoniou et al. 2002). Following the trade-off models of capital structure and According to (Siam et al. 2005 and Amidu 2007) large firms should accordingly employ more debt than smaller firms. Rajan and Zingales (1995) state that more total assets enhance the ability to diversify investments thus firms become less exposed for insolvency and bankruptcy. Another explanation of the positive relationship between size and leverage is that larger banks pay lower cost of funding (Ooi 1999 and Booth et al. 2001).

Finally, one of the purposes of this research is to investigate whether the recent financial crisis (2007/2008) has had any impact on the financial structure of the Jordanian banks. Morri and Artegiani (2015) found a significant impact of the financial crisis on the Euro firms. Danso and Adomako (2014) provide strong evidence of the effects of the financial crisis on the capital structure of firms in South Africa. We include this variable to investigate whether and how banks adjusted their capital structures due to the recent financial crisis. Following Morri and Artegiani (2015) we include a year dummy through which we give a value of one if the year is 2008 and after, while it takes a value of zero if the year is 2007 or before. The previous two methods test whether there is a significant difference between bank's capital structure decision and other main variables when comparing before and after financial crisis.
Additionally, a further investigation to compare the response of Jordanian banks to the financial crises this study employs a parametric analysis technique in order to distinguish whether the Jordanian banks adjust their behavior regarding capital structure as a consequence of the financial crisis of $2007 / 2008$. According to Fadem (2008) two-sample location test of the null hypothesis such that the means of two populations are equal, these tests are often referred to as independent samples t-tests, by way of they are typically useful when the statistical units underlying the two samples being compared are non-nested. We use the t-test parametric test to check the null hypothesis of: the mean of capital structure (Leverage) variables before Crisis equals the mean of capital structure variable after Crisis. That is, the global financial crisis has no impact on the capital structure variables. Therefore, we need to reject the null hypothesis to statistically prove that the means of the capital structure variables are different before and after the global financial crisis.

\section{Non - Parametric Analysis}

To make inferences about the impact of the financial crisis on the Jordanian banks' capital structure in our sample, a non-parametric statistical test is employed. The Wilcoxon test examines the hypothesis that two independent samples are from populations with the same distribution, which is also known as the Mann-Whitney two-sample statistic (Wilcoxon 1945 and Mann and Whitney 1947). The Wilcoxon matchedpairs signed rank test has been conducted to see whether the leverage ratios differ between the two periods (pre- and post-crisis). This test will also enable us to check if the drop/increase in a particular ratio (post-crisis as compared to pre-crisis period) is statistically significant or not. The advantage of the Wilcoxon test is that it does not require any assumption about the shape of the distribution (Al-Malkawi and Pillai 2013). To this end, the null hypothesis to be tested for the leverage ratio is below:

$\mathrm{HO}$ : the median of capital structure variables before the global financial crisis $=$ the median of capital structure variable after the global financial crisis.

The test is performed by first computing the median score for all observations combined, regardless of the sample group. Moreover, this test performed for all the determinants of capital structure explanatory variables and examined whether there is a difference between their values before and after the crises. 


\section{Sample and Data Collection}

To answer the questions of our study an annual panel data set has been used to conduct the empirical analysis. We employ samples contain all licensed Jordanian banks that meet the following conditions:

1. Jordanian Banks, both Islamic and Commercial.

2. Banks operating during the period from January 2003 until December 2015.

3. Data have been available about those banks' financial structure throughout the period of study.

There are 27 banks operating in Jordan, eleven banks are foreign banks that were licensed to practice banking business in Jordan. According to our data selection criteria, these foreign banks are excluded. That leaves our sample with the other sixteen domestic banks, three out of them are Islamic banks and thirteen are Commercial banks. The following table lists all domestic banks and their date of establishment.

To meet the second condition Jordan Dubai Islamic Bank was excluded from the sample because it was stablished in the year 2009, thus it wasn't operating during the sample period.

\section{Sample Period}

Beside the main objectives of analyzing the determinants of capital structure (leverage) of the banking sector in Jordan, we are interested in examining the impact of 2007/2008 financial crisis on Jordanian banks' main decisions. Accordingly, we employ the data sample during the period 2003 to 2015. Alongside with the fact that thirteen years is a fair enough sample periods to review and analyze the financial data required to achieve the study's objective employing panel data techniques. At the time of data collection, the author had access only for year 2016 annual reports and before. Unfortunately, not all banks reported the complete information for all of the required variables for 2016 therefore the sample stopped at 2015.

We have obtained a balanced panel data set. The required data set for the banks is obtained from the annual reports issued by the Jordanian banks, the Central Bank of Jordan and Amman stock exchange (ASE), in addition to the publications of the Association of banks in Jordan. Whilst, the required macroeconomic data are obtained from Jordanian Department of Statistics and Jordanian Ministry of Finance. In the following table, we present simple statistics for each variable included in the model.

The mean and standard deviation in Table 2 for the first dependent variable which is the total leverage ratio (leverage) equals 0.8722 and 0.0499 respectively which indicate kind of stability of the leverage ratio among the study period. As for the second dependent variable in second equation, STDTA, the mean is 0.7548 and the standard deviation is 0.0776 , and for LTDTA is 0.1174 and 0.0666 respectively. Having low standard deviation for all the variables indicates that the data points tend to be very close to the mean of the set of data. Except for Growth which have the highest standard deviation which means that data points are spread out over a wider range of value of the set of data. It worth mentioning that the mean of the growth (measured by the growth of the outstanding facilities) is $217 \%$ during the study period.

Table 1: List of Jordanian Banks

\begin{tabular}{|c|c|c|c|}
\hline Bank name & $\begin{array}{c}\text { Date of } \\
\text { establishment }\end{array}$ & Bank name & $\begin{array}{c}\text { Date of } \\
\text { establishment }\end{array}$ \\
\hline \hline Arab Bank & 1930 & Jordan Islamic Bank & 1978 \\
\hline Jordan Ahli Bank & 1956 & Investbank & 1989 \\
\hline Cairo Amman Bank & 1960 & Arab Banking (Corporation) Jordan & 1989 \\
\hline Bank of Jordan & 1960 & Bank Al-Etihad & 1991 \\
\hline The Housing Bank for Trade \& Finance & 1974 & Societe General_Jordan & 1996 \\
\hline Jordan Kuwait Bank & 1977 & Capital Bank & 1997 \\
\hline Arab Jordan Investment Bank & 1978 & Jordan Dubai Islamic Bank & 2009 \\
\hline Jordan Commercial Bank & 1978 & \\
\hline
\end{tabular}

Note: Banks establishment date is collected from Central Bank of Jordan. 
Table 2: Summary Statistics for Model's Variables

\begin{tabular}{|c|c|c|c|c|c|}
\hline Variable & Obs & Mean & Std. Dev. & Min & Max \\
\hline \hline Leverage & 195 & 0.872224 & 0.04995 & 0.780361 & 0.541497 \\
\hline STDTA & 195 & 0.754788 & 0.077609 & 0.029701 & 0.91457 \\
\hline LTDTA & 195 & 0.117437 & 0.066687 & -0.00969 & 0.060685 \\
\hline Perf & 195 & 0.01937 & 0.009795 & -0.64525 & 0.038675 \\
\hline Reta & 195 & 0.004114 & 0.053046 & 0.078204 & 0.734246 \\
\hline Liq & 195 & 0.409864 & 0.129499 & -0.99464 & 291.6976 \\
\hline Growth & 195 & 2.176149 & 22.93073 & 0.003915 & 0.053662 \\
\hline Tang & 195 & 0.016215 & 0.007895 & $5.84 \mathrm{E}-05$ & 0.029525 \\
\hline SDROA & 195 & 0.003468 & 0.004244 & -0.34617 & 1.014055 \\
\hline TAX & 195 & 0.286806 & 0.129643 & 7.824972 & 10.38985 \\
\hline Log Size & 195 & 9.098325 & 0.480206 & 0.00401 & 1.019485 \\
\hline Loan to deposits & 195 & 0.598436 & 0.180036 & 1.443936 & 2.5 \\
\hline
\end{tabular}

As shown in the correlation matrix table, the highest correlation coefficient is between Liquidity and loans to deposits ratio, as the value shown in the correlation matrix is equal to $41.8 \%$ but they are not perfectly correlated, on the other hand all correlation coefficients are weak which suggest that there is no multicollinearity problem. To make sure and to give solid evidence for the absence of the multicollinearity problem in our data sample; variance inflation factor (VIF) is performed.

The VIF factor is obtained by regressing each variable against the other variables in our model, then use the obtained $R$ square from each regression to calculate the VIF factor (VIF=1/1-Rsquare). If the VIF equals 5 or less, then that is a sign for nonmulticollinearity problem and otherwise there is a multicollinearity. According to the VIF results in Table
4, the highest VIF value is for the performance 1.51 which is lower than 5; therefore, we have emphasized the evidence of no multicollinearity in our data set.

\section{EMPIRICAL RESULTS AND DISCUSSION}

We employed the multivariate regression analysis to analyze the determinants of capital structure of the banking sector in Jordan during the period between 2003 and 2015. Moreover, the multivariate regression analysis also used in this study in order to figure out if the determinants of capital structure differs according to bank's characteristics, Islamic or Commercial bank. Finally, we employed parametric analysis and non parametric analysis to make implications about the impact of the financial crisis 2007/2008 on the Jordanian banks' capital structure.

Table 3: Correlation Matrix for Model's Explanatory Variables

\begin{tabular}{|c|c|c|c|c|c|c|c|c|c|}
\hline Perf & 1 & & & & & & & & \\
\hline Liq & 0.0462 & 0.0501 & 1 & & & & & & \\
\hline Growth & -0.0299 & 0.0026 & 0.0442 & 1 & & & & & \\
\hline SDROA & 0.1293 & -0.2905 & 0.1112 & 0.0171 & -0.0753 & 1 & & & \\
\hline TAX & -0.0901 & 0.1966 & 0.0841 & 0.0603 & 0.1358 & -0.3541 & 1 & & \\
\hline Size & -0.0263 & 0.2066 & -0.1293 & -0.1259 & -0.1504 & -0.3115 & 0.0226 & 1 & \\
\hline Loan/TD & 0.1758 & -0.06 & -0.4181 & 0.1243 & -0.1548 & 0.0459 & -0.0843 & -0.0878 & 1 \\
\hline
\end{tabular}


Table 4: The VIF Table

\begin{tabular}{|c|c|c|c|}
\hline Variable & Simple regression model & R square & VIF \\
\hline \hline Performance & perf $=\beta_{0}+\beta_{1}$ Reta $+\beta_{2}$ Liq $+\beta_{3}$ Growth $+\beta_{4}$ Tang $+\beta_{5}$ Risk $+\beta_{6}$ Tax $+\beta_{7}$ Size & $34.14 \%$ & 1.518372 \\
\hline Reta & Reta $=\beta_{0}+\beta_{1}$ perf $+\beta_{2}$ Liq $+\beta_{3}$ Growth $+\beta_{4}$ Tang $+\beta_{5}$ Risk $+\beta_{6}$ Tax $+\beta_{7}$ Size & $26.04 \%$ & 1.352082 \\
\hline Liq & Liq $=\beta_{0}+\beta_{1}$ perf $+\beta_{2}$ Reta $+\beta_{3}$ Growth $+\beta_{4}$ Tang $+\beta_{5}$ Risk $+\beta_{6}$ Tax $+\beta_{7}$ Size & $29.91 \%$ & 1.426737 \\
\hline Growth & Growth $=\beta_{0}+\beta_{1}$ perf $+\beta_{2}$ Reta $+\beta_{3}$ Liq $+\beta_{4}$ Tang $+\beta_{5}$ Risk $+\beta_{6}$ Tax $+\beta_{7}$ Size & $7.34 \%$ & 1.079214 \\
\hline Tang & Tang $=\beta_{0}+\beta_{1}$ perf $+\beta_{2}$ Reta $+\beta_{3}$ Liq $+\beta_{4}$ Growth $+\beta_{5}$ Risk $+\beta_{6}$ Tax $+\beta_{7}$ Size & $22 \%$ & 1.282051 \\
\hline Risk & Risk $=\beta_{0}+\beta_{1}$ perf $+\beta_{2}$ Reta $+\beta_{3}$ Liq $+\beta_{4}$ Growth $+\beta_{5}$ Tang $+\beta_{6}$ Tax $+\beta_{7}$ Size & $30.47 \%$ & 1.438228 \\
\hline Tax & Tax $=\beta_{0}+\beta_{1}$ perf $+\beta_{2}$ Reta $+\beta_{3}$ Liq $+\beta_{4}$ Growth $+\beta_{5}$ Tang $+\beta_{6}$ Risk $+\beta_{7}$ Size & $18.24 \%$ & 1.223092 \\
\hline Size & Size $=\beta_{0}+\beta_{1}$ perf $+\beta_{2}$ Reta $+\beta_{3}$ Liq $+\beta_{4}$ Growth $+\beta_{5}$ Tang $+\beta_{6}$ Risk $+\beta_{7}$ Tax & $21.71 \%$ & 1.277302 \\
\hline
\end{tabular}

\section{Empirical Results for Multivariate Regression Analysis}

The structure of our data sets is longitudinal which requires specific empirical techniques. Fixed effect and random effect techniques are both possible techniques for panel data set. Previous literature usually use fixed effect when studying banking system in Jordan (Ramadan et al. 2011 and Al-Jarrah 2010), however, we use Hausman test to help us determine which techniques is preferable. Accordingly, Hausman test was performed and the fixed effect seems to be more appropriate as we can't reject the null-hypothesis.

In our model we incorporate bank's type and the financial crises as dummy variables, bank's type dummy is time invariant as it is constant overtime for each bank and its value either zero for all years or one for all years. As we have mentioned earlier we are using the fixed effect method of analysis which requires not including time invariant variables (Jeffrey $M$. Wooldridge 2012).

Therefore, to capture the bank's type effect we regress the models three times, one time includes all banks in the sample, second time includes Commercial banks only and third time includes Islamic banks only. The other included dummy variable is financial crises and luckily it is not fixed over time and can be included in a fixed effect regression equation.

Examining the determinates of capital structure of Jordanian banks three regression equations were estimated, each one includes a different form of leverage as dependent variable, total debt ratio (Leverage), short term debt ratio (STDTA) and longterm debt ratio (LTDTA). The same set of explanatory variables, performance (Perf), retained earnings ratio (Reta), liquidity (Liq), facility growth (growth), tangibility (tang), effective tax rate (Tax), variation in income (Risk), effective tax rate (Tax), and banks size (Size), are used in each estimation.

Being aware of heteroscedasticity we performed the Modified Wald test for group wise heteroskedasticity that is used in fixed effect regression. The results of modified Wald test indicate evidence for heteroskedasticity existence in All Banks sample and the Commercial bank sample but in the Islamic bank sample there is no evidence for heteroskedasticity existence. Therefore, we employed fixed effect regression with robust standard errors in all banks sample and the Commercial banks sample analysis, and we employed fixed effect regression with regular standard error in Islamic banks sample analysis.

Heteroskedasticity exists if the error terms do not have constant variance, the Heteroskedasticity causes standard errors to be biased. OLS assumes that errors are both independent and identically distributed. Hence, when heteroskedasticity presents, robust standard errors tend to be more trustworthy deals with the problem of outliers in a regression. Robust regression uses a weighting scheme that causes outliers to have less impact on the estimates of regression coefficients. Additionally, the use of robust standard errors does not change the coefficient of estimates, but the test statistics give you reasonably accurate $p$ values (Jeffrey M. Wooldridge 2012).

The results are presented in Tables 5, 6 and 7 where the dependent variable in each table is (Leverage), (STDTA) and (LTDTA), respectively. Each table contains three panels; panel 1 comprises the 
results for all Jordanian banks sample, the second panel comprises the results for Jordanian Commercial banks sample and the last panel comprises the results for Jordanian Islamic banks sample.

\section{Determinants of Total Debt Ratio}

The below discussion explains and justifies the results which are compressed in Table 5 that presents the results of using the suitable regression in the leverage models (see equation (1)). The empirical results in panel 1 indicates that the determinants of total debt ratio for the whole sample (both Islamic and Commercial banks) are bank's performance, retained earnings, facility growth, risk, taxes, and financial crises. And they are the same for the Commercial banks in panel 2. However, the determinants of total debt ratio for Islamic banks are performance, liquidity, risk and tax. That seem to be different than those included in our models, as shown in panel 3.

Panel 1, panel 2 and panel 3 in Table 5 indicate negative and significant relationship between bank's performance and bank's total debt ratio. This is consistent with the pecking order theory and supported by many empirical studies (Titman and Wessels 1988; Myers 2001; Fama and French 2002; Hall et al. 2004; Chen and Strange 2005; Zou and Xiao 2006; Amidu 2007; Chen et al. 2014 and Danso and Adomako 2014) which indicates that the bank with a better performance will rely more on the internal sources of fund. Retained earnings seem to be among the determinants of total debt ratio for samples of all banks and Commercial banks, but it seems to be not significant for Islamic banks. The retained earnings increase the level of internal financing; thus Banks accumulate internal reserves, and this enables them to depend less on external funds (Titman and Wessels 1988 and Barton et al. 1989). This finding is consistent with the pecking order theory that suggests that profitable firms prefer internal financing to external financing.

The multivariate regression couldn't prove any evidence for liquidity to be a determinant of capital structure for all banks model and Commercial banks model (panel 1and 2) but it seems to be among the determinants of capital structure for Islamic banks (panel3). As shown in Table 5, the negative sign could infer that banks with more Liquidity do not need to be levered. The insignificancy of the relationship may refer to the fact that measuring banks liquidity is much more complex than the literature and our study measured it. The liquidity calculation in the banks follows a Basel regulation that requires daily internal data which is not available to the researchers.

The growth in the outstanding facilities lent by banks as a proxy for sales growth, correlated positively with total debt ratio as shown in Panel 1 and 2 in Table 5, however the correlation is weak but statistically significant. This result seems rational since the more

Table 5: Empirical Results of Robust Estimation of Fixed Effect Method for the Determinants of Capital Structure Model (the Dependent Variable is the Total Debt Ratio (Leverage))

\begin{tabular}{|c|c|c|c|c|c|c|c|c|c|c|c|c|}
\hline \multirow[b]{2}{*}{ Leverage } & \multicolumn{4}{|c|}{ Panel 1: All Banks } & \multicolumn{4}{|c|}{ Panel 2: Commercial Banks } & \multicolumn{4}{|c|}{ Panel 3: Islamic banks } \\
\hline & Coef. & $P>|t|$ & Coef. & $P>|t|$ & Coef. & $P>|t|$ & Coef. & $P>|t|$ & Coef. & $P>|t|$ & Coef. & $P>|t|$ \\
\hline Perf & -0.7911 & 0.005 & -0.7207 & 0.005 & -0.6667 & 0.025 & -0.6468 & 0.017 & -1.0558 & 0.0850 & -1.3396 & 0.0050 \\
\hline Reta & -0.6238 & 0.000 & -0.642 & 0.000 & -0.6247 & 0.000 & -0.6298 & 0.000 & -0.1840 & 0.7230 & & \\
\hline Liq & -0.0361 & 0.442 & & & -0.0102 & 0.812 & & & -0.0901 & 0.0800 & -0.0845 & 0.0020 \\
\hline Growth & $0.1042^{*}$ & 0.008 & $0.1143^{*}$ & 0.003 & $0.1115^{\star}$ & 0.003 & $0.1143^{*}$ & 0.002 & 0.0005 & 0.1890 & & \\
\hline Tang & -0.4709 & 0.407 & -0.3864 & 0.477 & -0.3684 & 0.492 & -0.3446 & 0.522 & -0.4604 & 0.8260 & & \\
\hline Risk & $-0.0392^{*}$ & 0.025 & $-0.0343^{*}$ & 0.011 & $-0.0367^{*}$ & 0.024 & $-0.0353^{*}$ & 0.009 & 3.7881 & 0.2640 & 4.6616 & 0.0950 \\
\hline TAX & 0.0326 & 0.084 & 0.033 & 0.083 & 0.0364 & 0.049 & 0.0366 & 0.050 & -0.3714 & 0.0360 & -0.4185 & 0.0040 \\
\hline Size & -0.0111 & 0.715 & -0.0015 & 0.958 & -0.0129 & 0.678 & -0.0102 & 0.696 & 0.0014 & 0.9770 & & \\
\hline \multirow[t]{2}{*}{ Crisis } & -0.02 & 0.006 & -0.0162 & 0.046 & -0.0162 & 0.031 & -0.0151 & 0.069 & -0.0291 & 0.0660 & -0.0284 & 0.0100 \\
\hline & \multicolumn{4}{|c|}{ No. Observation $=195$} & \multicolumn{4}{|c|}{ No. Observation $=169$} & \multicolumn{4}{|c|}{ No. Observation $=26$} \\
\hline R-Seq & \multicolumn{2}{|c|}{0.737} & \multicolumn{2}{|c|}{0.733} & \multicolumn{2}{|c|}{0.743} & \multicolumn{2}{|c|}{0.742} & \multicolumn{2}{|c|}{0.758} & \multicolumn{2}{|c|}{0.712} \\
\hline F Value & \multicolumn{2}{|c|}{93.11} & \multicolumn{2}{|c|}{98.08} & \multicolumn{2}{|c|}{75.42} & \multicolumn{2}{|c|}{86.26} & \multicolumn{2}{|c|}{3.83} & \multicolumn{2}{|c|}{7.42} \\
\hline Prob $>$ F & \multicolumn{2}{|c|}{0} & \multicolumn{2}{|c|}{0} & \multicolumn{2}{|c|}{0} & \multicolumn{2}{|c|}{0} & \multicolumn{2}{|c|}{0.02} & \multicolumn{2}{|c|}{0.0011} \\
\hline
\end{tabular}

${ }^{*}$ The growth and the risk coefficients are multiplied by 1000 . 
banks lent requires much more debt or deposits. In the same context (Amidu 2007) shows a positive relationship between growth and leverage, moreover, he argued that banks with a relatively high growth rate will tend to look at short-term less secured debt first, then to longer-term more secured debt to finance their growth. According to the pecking order arguments, growing firms have greater demand on their internally generated fund. Empirical studies find that future growth is positively related to leverage (Michaelas et al. 1999). However, the growth variable is not significant in the Islamic banks model as shown in panel 3 in Table 5. Accordingly, we can argue that even though the growth is not among the determinants of Islamic banks total debt ratio, but it's among the determinant of Jordanian banks total debt ratio.

The three Panels in Table $\mathbf{5}$, show statistically insignificant negative correlation between tangibility and total debt ratio (leverage). Thus, multivariate regression couldn't provide evidence that tangibility (which is measured by the fixed assets to total assets ratio) is among the determinants of the capital structure in the Jordanian banks. Amidu (2007) examins a negative relationship between tangibility or assets structure and leverage in Ghana's bank without any explanation. On the other side, consistent with the argument of Myers (1977) that tangible assets support higher debt level. Harris and Raviv (1991); Rajan and Zingales (1995); Bevan and Danbolt (2000); Omet and Nobanee (2001) and Buferna et al. (2005) suggest that tangible assets are positively correlated with leverage ratio, because firms may use fixed assets as collateral to issue more debt to take advantage of this opportunity.

The risk variable (measured as variability in bank's net income) is found to be one of determinants of longterm debt ratio. Statistically significant correlation between risk and total debt ratio is presented in Panel 1, panel 2 and Panel 3 in Table 5. The results in panel 1 and panel 2 indicate the riskier banks are less attractive to hold the customers deposits. Customers prefer to deposit their cash in the less risky banks. According to the trade-off theory; firms with higher risk expected to have lower leverage ratio since the volatility of profit leads to higher bankruptcy costs. The negative relationship between risk and leverage is consistent with the results of (Ooi 1999; Titman and Wessels 1988 and Danso and Adomako 2014). However, the results in panel 3 (Islamic banks model) show a statistically significant relationship between risk and leverage that shows the Islamic banks are more trustworthy to be levered in the risky conditions taking in the consideration that the variability in net income for both Islamic and Commercial banks had almost the same trend - with more positive variation in the Islamic banks net income trend - among our sample period.

The effective tax rate seems to be one of the determinants of the total debt ratio. The results shown in Table $\mathbf{5}$ indicate a positive and statistically significant relationship between Tax and leverage in Panel 1 and Panel 2 while a negative and statistically significant relationship between Tax and leverage in Panel 3 .The results which is consistent with (Amidu 2007) who found a positive significant relationship between the effective tax rate and the leverage in Ghana's banks as he considered bank's taxes as additional charge. That is, the effective tax rate presents a direct cost or expenses which is constitutes in average about $28.7 \%$ of the banks income in our sample, this cost must be paid whither funded from internal or external sources. Based on the multivariate regression results we can predict that Jordanian banks in general and Commercial banks are funding the tax expenses from external debt.

Islamic banks that had already more short debt to total assets ratio and leverage ratio do not need to lever more to pay for tax. Thus, positive relationship is not expected in this case. Furthermore, the effective tax rate are depending directly and extrusive to the banks performance which already have negative relationship with the leverage ratio, we can interpret the negative significant relationship between Tax and leverage ratio in the Islamic banks model are actually reflect the relationship between banks performance and leverage, and we can argue that the effective tax rate is not among the determinants of Islamic banks leverage ratio.

The regressions result that compressed in the three panels of Table $\mathbf{5}$ couldn't prove that bank size is among the determinants of leverage ratio, the results show a statistically insignificant negative relationship between bank size and total debt ratio. Though this relationship has been discussed repeatedly in the literature, according to (Siam et al. 2005 and Amidu 2007) large firms should accordingly employ more debt than smaller firms. Rajan and Zingales (1995) state that more total assets enhance the ability to diversify investments thus firms become less exposed for insolvency and bankruptcy. Beside the argument that larger banks pay lower cost of funding (Ooi 1999 and Booth et al. 2001). These results are completely 
different. We may argue that Jordanian banks might differ in size, but this doesn't affect their policies toward the capital structure, besides there is no substantial disparity in the Jordanian banks' size among our sample.

The financial crisis has negatively affected the Jordanian banks leverage, as the results indicate a negative and statistically significant relationship between the dummy variable crisis and total debt ratio in panel 1, panel 2 and panel 3 as shown in Table 5 . This result is consistent with Danso and Adomako (2014) when they found that the global financial crisis affected the capital structure in South Africa firms. The finical crisis of 2007/2008 has affected the liquidity in all sectors leading to reduce the leverage in the banks noting that the mean of the deposits on the Jordanian banks liability is $86.5 \%$. Accordingly, we have strong evidence that the Jordanian banks' capital structure has been affected, and they adjusted their behavior regarding capital structure as a consequence of the global financial crisis of $2007 / 2008$.

\section{Determinants of Short-Term Debt to Total Assets Ratio}

The below discussion explains and justifies the empirical results of using the proper multivariate regressions on the short-term debt to total assets ratio model (see equation (2) to examine the determinants of short-term debt to total assets ratio in the Jordanian banks, the empirical results are presented in Table 6 .

Panel 1 and Panel 2 present the empirical results of using robust fixed effect regression on the short-term debt to total assets ratios model using all Jordanian Banks sample (in panel 1) and Jordanian Commercial banks sample (in panel 2). The determinants of shortterm debt to total assets ratio for all banks model and Commercial banks model are bank's performance, retained earnings, facility growth, risk, taxes, and financial crises. While the determinants of long-term debt to total assets ratio for all banks model and Commercial banks model are performance, liquidity, growth, risk and tax. Panel 3 presents the empirical results of using fixed effect regression on short term debt to total assets ratio model using the Jordanian Islamic banks data sample. The presented results indicate that the determinants of short-term debt to total assets ratio for the Jordanian Islamic banks among our thesis sample period are bank's performance, Liquidity, risk, taxes, and financial crises. while the determinants of Jordanian Islamic banks capital structure measured by leverage ratio are: performance, liquidity, risk and tax.

There is a statistically negative relationship between profitability and short-term debt ratio appears as it appears in panel 1, panel 2 and panel 3 in Table 6 . This relationship shows that profitable banks use less short-term debt, the result is coinciding with Amidu (2007). Moreover, this result agree with our previous findings and results in Table 6, insuring that the bank's profitability is an important determinant of capital structure in the Jordanian banks, whether it's Commercial or Islamic bank.

The regression results in the three panels in Table 6 couldn't prove an evidence of correlation between the retained earnings and the short-term debt to total assets ratio (STDTA). Although the results in the three panels in Table 6 couldn't prove an evidence of correlation between the tangibility and the short-term debt to total assets ratio (STDTA). Contrary to Amidu (2007) the empirical evidence, the results show a negative and statistically insignificant correlation between the retained earnings and the short term debt ratio (STDTA) as well between operating assets ratio (tangibility) and short term debt to total assets (STDTA); these two results ensure that fixed assets in Jordanian banks are funded by retained earnings and long term liabilities, in other words, the uses of the retained earnings in the Jordanian banks are generally the same uses of the long term liabilities such as funding fixed assets or noncurrent assets. This argument is supported by the results in Table 7 that shows negative and significant relationship between long term debt to total assets ratio and the retained earnings. Consequently, it makes sense to find that tangibility and retained earnings are not among the determinants of short-term debt to total assets (STDTA).

Justifying the negative and statistically significant relationship between liquidity and short-term debt ratio in panel 1 and panel 3 , while the results indicate an insignificant negative relationship in panel 2 . The negative relationship is expected as banks with high liquidity do not need more short-term debt (deposits) that banks have to pay interest to hold as for saving accounts and time deposits. Moreover, the negative relationship was expected to the Islamic banks too, as saving account and time deposits are sharing the banks' profits and risk according to Modaraba principle which is compatible with Islamic Sharia. This result is supported by Ozkan (2001); Antoniou et al. (2002) and 
Table 6: Empirical Results of Robust Estimation of Fixed Effect Method for the Determinants of Capital Structure Model (the Dependent Variable is the Short-Term Debt Ratio)

\begin{tabular}{|c|c|c|c|c|c|c|c|c|c|c|c|c|}
\hline \multirow[b]{2}{*}{ STDTA } & \multicolumn{4}{|c|}{ Panel 1: All Banks } & \multicolumn{4}{|c|}{ Panel 2: Commercial Banks } & \multicolumn{4}{|c|}{ Panel 3: Islamic banks } \\
\hline & Coef. & $P>|t|$ & Coef. & $P>|t|$ & Coef. & $P>|t|$ & Coef. & $P>|t|$ & Coef. & $P>|t|$ & Coef. & $P>|t|$ \\
\hline Perf & -1.9246 & 0.000 & -1.7239 & 0.001 & -1.7373 & 0.002 & -1.6019 & 0.002 & -3.0505 & 0.0010 & -2.3605 & 0.0010 \\
\hline Reta & -0.0094 & 0.891 & -0.0613 & 0.357 & -0.0082 & 0.909 & -0.0432 & 0.508 & -0.1378 & 0.8350 & & \\
\hline Liq & -0.103 & 0.087 & & & -0.0695 & 0.257 & & & -0.0755 & 0.2330 & -0.1061 & 0.0040 \\
\hline Growth & 0.0681 & 0.104 & 0.0969 & 0.027 & 0.0749 & 0.075 & 0.0944 & 0.034 & 0.0003 & 0.4990 & & \\
\hline Tang & 0.0734 & 0.933 & 0.314 & 0.73 & 0.1822 & 0.840 & 0.3444 & 0.712 & 3.7149 & 0.1830 & & \\
\hline Risk & -0.0878 & 0.000 & -0.0738 & 0.001 & -0.0851 & 0.000 & -0.0757 & 0.001 & 9.8935 & 0.0350 & 8.3757 & 0.0410 \\
\hline TAX & 0.0578 & 0.017 & 0.0591 & 0.023 & 0.0645 & 0.009 & 0.0654 & 0.013 & -0.6591 & 0.0070 & -0.6698 & 0.0020 \\
\hline Size & 0.0055 & 0.904 & 0.0328 & 0.484 & -0.001 & 0.982 & 0.0175 & 0.686 & 0.0574 & 0.3640 & & \\
\hline \multirow[t]{2}{*}{ Crisis } & -0.0218 & 0.200 & -0.0108 & 0.532 & -0.0166 & 0.344 & -0.0091 & 0.596 & -0.0603 & 0.0070 & -0.0336 & 0.0270 \\
\hline & \multicolumn{4}{|c|}{ No. Observation $=195$} & \multicolumn{4}{|c|}{ No. Observation $=169$} & \multicolumn{4}{|c|}{ No. Observation $=26$} \\
\hline R-Seq & \multicolumn{2}{|c|}{0.224} & \multicolumn{2}{|c|}{0.195} & \multicolumn{2}{|c|}{0.203} & \multicolumn{2}{|c|}{0.188} & \multicolumn{2}{|c|}{0.8294} & \multicolumn{2}{|c|}{0.7462} \\
\hline F Value & \multicolumn{2}{|c|}{51.76} & \multicolumn{2}{|c|}{424.38} & \multicolumn{2}{|c|}{89.93} & \multicolumn{2}{|c|}{1124.08} & \multicolumn{2}{|c|}{5.94} & \multicolumn{2}{|c|}{8.82} \\
\hline Prob $>F$ & \multicolumn{2}{|c|}{0} & \multicolumn{2}{|c|}{0} & \multicolumn{2}{|c|}{0} & \multicolumn{2}{|c|}{0} & \multicolumn{2}{|c|}{0.0038} & \multicolumn{2}{|c|}{0.0005} \\
\hline
\end{tabular}

-The growth and the risk coefficients are multiplied by 1000 .

Siam et al. (2005) as they find a significant negative relationship between leverage and bank's liquidity.

Supporting Amidu (2007) argument that banks with a relatively high growth rate tend to look at short-term less secured debt first, then to longer-term more secured debt to finance their growth. The results indicate a positive and statistically significant relationship between growth and short-term debt to total assets in panel 1 and panel 2. However, the correlation is weak as shown in the Table 6. Unlike Islamic banks model regression's results, regarding to the results in panel 3 , insignificant relationship between growth and short-term debt to total assets (STDTA) appears. That may refer to the high level of short-term liabilities (deposits) in Jordanian Islamic bank among the sample period. Moreover, Jordanian Islamic banks were suffering - in the sample period - from the limitation of using the excess reserve where it cannot be utilized through the Central Bank of Jordan overnight windows of loans because it is contrary to Sharia principles. So, any growth in the lent facilities remained better use for Islamic banks existing deposits and didn't need increasing the short-term liabilities.

Assets tangibility is not among the determinants of short-term debt to total assets ratio. The results indicate a positive and statistically insignificant relationship between tangibility and short-term debt to total assets in the three models as shown in panel 1 , panel 2 and panel 3 in Table 6 . The short-term debt in the banks are mainly the customer deposits, so the results of this model regression indicates that there is no correlation between banks fixed asset (assets structure) and the short-term debt (customer deposits), thus supporting that banks aren't using the short-term debt to finance their fixed assets.

Additionally, risk is among the determinants of short-term debt to total assets ratio (STDTA), the results in Table 6 indicate a negative and statistically significant relationship between risk (variability in income) and short-term debt to total assets in panel 1 and panel 2. However, that supports our argument that the riskier bank is less attractive to hold the customer deposits, in other words customers prefer to deposit their cash in the less risky banks. However, risk seems also among Islamic Jordanian banks determinants of short-term debt to total assets ratio (STDTA).

The coefficient of the tax variable suggests a positive and statistically significant relationship between the effective tax rate (Tax) and short-term debt to total assets (STDTA) for All banks model and Commercial banks model as shown in panel 1 and panel 2. But a negative and statistically significant relationship between Islamic banks effective tax rate (Tax) and short-term debt to total assets (STDTA). These results also support our argument that the banks used short term debt to fund the taxation expenses. As 
well as support our argument that Islamic banks had have enough deposits (STDTA) in our sample period that increases the level of Islamic banks' liquidity, so they didn't have use external sources to pay tax. Moreover, the results support the whole discussion of the results in Table 5. Subsequently, Tax variable is among the determinants of short-term debt to total assets ratio (STDTA) in all our samples.

Bank size have no influence on the capital structure decision, since the banks size variable measured by the nature logarithm of banks total assets. Bank size has no correlation with the short-term debt to total assets ratio (STDTA) as shown in Table 6 or with total debt ratio (leverage) as shown in Table $\mathbf{5}$. These results appeared to be consistent with Abu Mouamer (2011).

The regression results in Table 6 indicate a negative and statistically insignificant relationship between the crisis dummy variable and short-term debt to total assets ratio (STDTA) in panel 1 and panel 2, however panel 3 indicates a negative and statistically significant relationship between the crisis dummy variable and Islamic banks short term debt to total assets (STDTA). Thus, we have solid evidence for that the global financial crisis affected Islamic banks (STDTA) negatively.

\section{Determinants of Long-Term Debt to Total Assets Ratio}

The below discussion explains and justifies the results that are compressed in Table 7 which present the results of using Robust fixed effect regression for the Long-term debt to total assets models (see equation (3)).

In term of the determinants of long-term debt to total assets ratio (LTDTA) there is no significant difference between Islamic banks or Commercial banks. The results for the both banks type of the following explanatory variables: retained earnings ratio (Reta), liquidity (Liq), facility growth (growth), tangibility (tang), effective tax rate (Tax), effective tax rate (Tax), and banks size (Size), were all not significant, thus our models couldn't provide evidence whether there is a relationship between any of them and the long term debt to total assets ratio(LTDTA), these results supported in the literature by Mouamer (2011) who examines the relationship between the capital structure and debt lifetime among listed companies in Palestine stock market found no significant relationship between the LTD and STD on the one hand and age, growth, liquidity, tangibility, and size on the other hand.

The results in Table 7 indicate a positive relationship between profitability and long-term debt to total assets. Which seems to be in contrast with the argument that profitable firms use less debt and with Amidu's research empirical results in Amidu (2007). It is good to know that the nature of banks' long-term liabilities is completely different than the long-term liabilities in other sectors. According to bank's annual reports, long-term liabilities are not necessarily to be just loans, banks' long-term debt liabilities (nondeposits liabilities) contain cash margin, tax provision and sold notes. Cash margin which considered as liabilities on the bank, are originated from granting direct and non-direct facilities which involve potential return for the bank, moreover, income tax provision and sold notes which are intermediate accounts be issued through a bank papers it is considered as an obligation of bank to pay a certain amount of (certified) checks and these checks are issued for several reasons, either at the client's request, or to pay a type of financing for customers and suppliers.

The results indicate a statistically significant relationship between risk (variability in net income) and long-term debt to total assets (LTDTA) in Table 7 three panels. Therefore, we can prove that RISK is among the determinants of long-term debt to total assets (LTDTA).

As Table 8 shown it's clear that performance and risk are the most common among the determinates of all capital structure level, followed by the effective tax rate. While growth and retained earning seems among the determinates of specific levels of capital structure. Moreover, size and tangibility are not among the determinates of capital structure.

\section{Parametric Analysis and Non - Parametric Analysis Results}

In this part we interpret the results of two tests. A parametric t-test assuming unequal variances has been performed to test for the significance of mean differences in the capital structure variables in addition to determinants of capital structure variables. And a non-parametric Wilcoxon sum rank z-test has also been also performed to test for the significance of median differences in each capital structure variables. The differences have been calculated based on fiveyear period prior and post the global financial crisis 2008. 
Table 7: Empirical Results of Robust Estimation of Fixed Effect Method for the Determinants of Capital Structure Model (the Dependent Variable is the Long Term Debt Ratio)

\begin{tabular}{|c|c|c|c|c|c|c|c|c|c|c|c|c|}
\hline \multirow[b]{2}{*}{ LTDTA } & \multicolumn{4}{|c|}{ Panel 1: All Banks } & \multicolumn{4}{|c|}{ Panel 2: Commercial Banks } & \multicolumn{4}{|c|}{ Panel 3: Islamic banks } \\
\hline & Coef. & $P>|t|$ & Coef. & $P>|t|$ & Coef. & $P>|t|$ & Coef. & $P>|t|$ & Coef. & $P>|t|$ & Coef. & $P>|t|$ \\
\hline Perf & 1.1335 & 0.005 & 1.0032 & 0.011 & 1.0707 & 0.008 & 0.9552 & 0.014 & 1.9946 & 0.0000 & 1.0209 & 0.0250 \\
\hline Reta & -0.6144 & 0.000 & -0.5807 & 0.000 & -0.6165 & 0.000 & -0.5866 & 0.000 & -0.0462 & 0.8790 & & \\
\hline Liq & 0.0669 & 0.213 & & & 0.0593 & 0.286 & & & -0.0147 & 0.6030 & 0.0215 & 0.3480 \\
\hline Growth & 0.0361 & 0.304 & 0.0174 & 0.608 & 0.0366 & 0.327 & 0.0199 & 0.585 & 0.0002 & 0.4080 & & \\
\hline Tang & -0.5443 & 0.566 & -0.7005 & 0.438 & -0.5506 & 0.572 & -0.689 & 0.457 & -4.1753 & 0.0050 & & \\
\hline Risk & 0.0486 & 0.059 & 0.0395 & 0.082 & 0.0485 & 0.067 & 0.0404 & 0.081 & -6.1054 & 0.0080 & -3.7141 & 0.1820 \\
\hline TAX & -0.0252 & 0.306 & -0.026 & 0.309 & -0.0281 & 0.262 & -0.0288 & 0.267 & 0.2877 & 0.0090 & 0.2513 & 0.0650 \\
\hline Size & -0.0166 & 0.596 & -0.0343 & 0.249 & -0.012 & 0.699 & -0.0277 & 0.34 & -0.0560 & 0.0690 & & \\
\hline \multirow[t]{2}{*}{ Crisis } & 0.0017 & 0.902 & -0.0054 & 0.739 & 0.0003 & 0.981 & -0.006 & 0.71 & 0.0312 & 0.0030 & 0.0052 & 0.6000 \\
\hline & \multicolumn{4}{|c|}{ No. Observation $=195$} & \multicolumn{4}{|c|}{ No. Observation $=169$} & \multicolumn{4}{|c|}{ No. Observation $=26$} \\
\hline R-Seq & \multicolumn{2}{|c|}{0.482} & \multicolumn{2}{|c|}{0.472} & \multicolumn{2}{|c|}{0.476} & \multicolumn{2}{|c|}{0.468} & \multicolumn{2}{|c|}{0.8506} & \multicolumn{2}{|c|}{0.4701} \\
\hline F Value & \multicolumn{2}{|c|}{392.01} & \multicolumn{2}{|c|}{140.01} & \multicolumn{2}{|c|}{445.25} & \multicolumn{2}{|c|}{190.55} & \multicolumn{2}{|c|}{6.96} & \multicolumn{2}{|c|}{2.66} \\
\hline Prob $>\mathrm{F}$ & \multicolumn{2}{|c|}{0} & \multicolumn{2}{|c|}{0} & \multicolumn{2}{|c|}{0} & \multicolumn{2}{|c|}{0} & \multicolumn{2}{|c|}{0.0019} & \multicolumn{2}{|c|}{0.0648} \\
\hline
\end{tabular}

-The growth and the risk coefficients are multiplied by 1000 .

Table 8: Summary of the Empirical Results for all Determinants of Capital Structure Models

\begin{tabular}{|c|c|c|c|c|c|c|c|c|c|}
\hline & \multicolumn{3}{|c|}{ ALL BANKS } & \multicolumn{3}{|c|}{ COMMERCIAL BANKS } & \multicolumn{3}{|c|}{ ISLAMIC BANKS } \\
\hline & LEV. & STDTA & LTDTA & LEV. & STDTA & LTDTA & LEV. & STDTA & LTDTA \\
\hline Perf & - & - & + & - & - & + & & - & + \\
\hline Reta & - & Insig. & - & - & Insig. & - & Insig. & Insig. & Insig. \\
\hline Liq & Insig. & - & Insig. & Insig. & Insig. & Insig. & - & Insig. & Insig. \\
\hline Growth & + & + & Insig. & + & + & Insig. & Insig. & Insig. & Insig. \\
\hline Tang & Insig. & Insig. & Insig. & Insig. & Insig. & Insig. & Insig. & Insig. & - \\
\hline Risk & - & - & + & - & - & + & Insig. & + & - \\
\hline TAX & + & + & Insig. & + & + & Insig. & - & - & + \\
\hline Size & Insig. & Insig. & Insig. & Insig. & Insig. & Insig. & Insig. & Insig. & - \\
\hline Crisis & - & Insig. & Insig. & - & Insig. & Insig. & - & - & +/Insig. \\
\hline
\end{tabular}

The empirical analysis continues with the parametric test of testing the hypothesis of no difference between the mean of capital structure variables before the global financial crisis and after the global financial crisis. The results reveal significance expansion in the mean of capital structure when measured by total debt ratio and the long term to total assets ratio.

The Wilcoxon rank sum test has also been performed to check the hypothesis that the median before and after the financial crisis of capital structure and performance variables are different. Jordanian banks loan to deposits ratio seems to be affected negatively by the global financial crisis, the Jordanian banks couldn't employ the customers' deposits in the financing activities after the crisis as well as they did before the crisis.

Assets structure variable measured by fixed assets to total assets shows significant decline after the crisis as the parametric t-test results claims. According to the parametric t-test, we couldn't reject the null hypothesis that claims no difference between the variables (short term debt to total assets, retained earnings to total assets, risk and tax). The results of The Wilcoxon rank 
Table 9: The Parametric and Non- Parametric Analysis Results

\begin{tabular}{|c|c|c|c|c|c|}
\hline \multirow{4}{*}{ Variable } & \multicolumn{3}{|c|}{ Parametric Analysis (Mean t- test) } & \multicolumn{2}{|c|}{$\begin{array}{c}\text { Non - Parametric Analysis (Wilcoxon } \\
\text { test) }\end{array}$} \\
\hline & \multirow{2}{*}{\multicolumn{3}{|c|}{$\begin{array}{l}\text { Two group mean comparison test before and after the global } \\
\text { financial crisis } \\
\mathrm{H}_{0} \text { : The mean of the variable before Crisis = the mean of the } \\
\text { variable after Crisis. }\end{array}$}} & \multirow{2}{*}{\multicolumn{2}{|c|}{$\begin{array}{c}\text { Median ranks sum test before and after } \\
\text { the global financial crisis } \\
H_{0}: \text { The median of the variable before } \\
\text { Crisis = the median of the variable after } \\
\text { Crisis. }\end{array}$}} \\
\hline & & & & & \\
\hline & Diff & $\operatorname{Pr}(|\mathrm{T}|>|\mathrm{t}|)$ & S. E. & $Z=$ & Prob $>|z|$ \\
\hline Leverage & 0.023 * & 0.003 & 0.008 & 3.312 * & 0.001 \\
\hline STDTA & -0.003 & 0.776 & 0.012 & 0.347 & 0.729 \\
\hline LTDTA & 0.027 * & 0.010 & 0.010 & 1.820 ** & 0.069 \\
\hline Reta & -0.011 & 0.186 & 0.008 & -0.511 & 0.610 \\
\hline Liq & 0.178 * & 0.000 & 0.015 & 9.127 * & 0.000 \\
\hline Growth & 3.524 & 0.327 & 3.586 & 4.726 * & 0.000 \\
\hline Tang & -0.003 * & 0.005 & 0.001 & -3.079 * & 0.002 \\
\hline Risk & -9.388 & 0.345 & 9.902 & 1.944 ** & 0.052 \\
\hline TAX & 0.002 & 0.930 & 0.020 & 0.789 & 0.430 \\
\hline Size & -0.281 * & 0.000 & 0.072 & -4.496 * & 0.000 \\
\hline Loan/TD & -0.091 * & 0.001 & 0.027 & -3.528 * & 0.000 \\
\hline
\end{tabular}

Note: *: indicates significant at $5 \%$ level, ${ }^{* *}$ : indicates significant at $10 \%$ level.

sum test that presented in Table 9 are consistent with those of $\mathrm{t}$-test mean hypothesis testing.

\section{CONCLUSION AND POLICY IMPLICATION}

This research investigates the capital structure determining variables in the Jordanian banking sector during the period between 2003 and 2015. We also examine wither the determinants of capital structure differ according to bank's type. Additionally, the research tries to distinguish whether the Jordanian banks adjust their behavior regarding capital structure because of the financial crisis of 2007/2008. The study uses multivariate regression techniques of panel data besides the parametric and non-parametric analysis. Empirically, the findings suggest a variation of capital structure determinants based on the variable of measurement. However, the analysis confirms that bank's profitability and bank's risk are major components of the capital structure decision regardless of its measurement variable. In addition to these two variables, liquidity, growth and taxes are important variable in the short-term debt financing, and retained earnings is important to the long-term financing. Empirically proven that Jordanian banks' capital structure decision is affected by the global financial crisis 2007/2008 and by bank type. Jordanian banks might differ in size, but this doesn't affect their policies toward the capital structure. The empirical results are consistent with the pecking order theory that profitable firms prefer to use more of their internal sources of funds rather than debt financing.

Due to the importance of the capital structure decision for banks and non-banks firms and based on our finding, the policy makers in Jordan and may in other similar countries should pay attention to capital requirement regulations as the determinants of leverage among banks are different based on the business model whether commercial or Islamic.

\section{REFERENCES}

Amidu, M. (2007). Determinants of capital structure of banks in Ghana: an empirical approach. Baltic Journal of Management, 2(1), 67-79. https://doi.org/10.1108/17465260710720255

Amjad, S.Bilal and Tufail, S. (2013).Determinants of Capital Structure What can be the Determinants of Capital Structure of Banking Sector of Pakistan?3rd international Conference on Business Management.

Antoniou, A., Guney, Y. and Paudyal, K. (2002) Determinants of Corporate Capital Structure: Evidence from European Countries, University of Durham, Working paper, pp: 1-8. https://doi.org/10.2139/ssrn.302833

Antwi. S, Mills. E, Zhao. X, 2012. Capital Structure and Firm Value: Empirical Evidence from Ghana. International Journal of Business and Social Science Vol. 3 No. 22, pp 13-111.

Baker, Malcolm P. and Wurgler, Jeffrey, Market Timing and Capital Structure. Journal of Finance, Vol. 57, No. 1, pp. 1-32, 
February 2002. Available at SSRN: http://ssrn.com/abstract=276574

https://doi.org/10.1111/1540-6261.00414

Barton, S.L., Hill, N.C. and Sundaram, S., 1989. An empirical test of stakeholder theory predictions of capital strucuture. Financial Management, 18, 1, 36-44. https://doi.org/10.2307/3665696

Bennett M, Donnelly R (1993). The Determinants Of Capital Structure: Some UK evidence. Br. Account. Rev., 25: 43-59. https://doi.org/10.1006/bare.1993.1005

Berger, Herring and Szegö, (1995). The Relationship between Capital and Earnings in Banking, Journal of Money, Credit, and Banking, 27: 432-456. https://doi.org/10.2307/2077877

Bevan, A. and Danbolt, J. (2000) Dynamics in the Determinants of Capital Structure in the UK,University of Glasgow, Working paper, pp: 1-10. https://doi.org/10.2139/ssrn.233551

Booth, L., Aivazian, V., Demirguc-Kunt, A. and Maksimovic, V. (2001) Capital Structures in Developing Countries, The Journal of Finance, LVI: 87-130. https://doi.org/10.1111/0022-1082.00320

Bradley, M., Jarell, G. and Kim, E.H., 1984. On the Existence of an Optimal Capital Structure: Theory and Evidence. The Journal of Finance, 39, 857-878 https://doi.org/10.1111/j.1540-6261.1984.tb03680.x

Buferna, F., Bangassa, K. and Hodgkinson, L. (2005) "Determinants of Capital Structure:Evidence from Libya", University of Liverpool, Working Paper, pp: 2-7.

Cassar, G. \& Holmes, S., 2003. Capital Structure and Financing of SMEs: Australian evidence. Accounting and Finance, 43, 123-147. https://doi.org/10.1111/1467-629X.t01-1-00085

Chen, J. and Strange, R. (2005), "The determinants of capital structure: evidence from Chinese listed companies", Economic Change and Restructuring, Vol. 38 No. 1, pp. 1135. https://doi.org/10.1007/s10644-005-4521-7

Chen. J, Jiang, C and Lin. Y,(2014), "What determine firms' capital structure in China?", Managerial Finance, Vol. 40,Iss. 10,pp. $1024-1039$. https://doi.org/10.1108/MF-06-2013-0163

Chittenden, Francis, Graham Hall, and Patrick Hutchinson, 1996, Small firm growth, access to capital markets and financial structure: Review of issues and an empirical investigation, Small Business Economics 8, 59-67. https://doi.org/10.1007/BF00391976

Danso, A., \& Adomako, S. (2014). The financing behaviour of firms and financial crisis. Managerial Finance, 40(12), 1159-1174. https://doi.org/10.1108/MF-04-2014-0098

Deesomsak, R. and Paudyal, K. and Pescetto, G. (2004) 'The determinants of capital structure: evidence from the Asia Pacific region.', Journal of multinational financial management., 14 (4-5). pp. 387-405.

https://doi.org/10.1016/j.mulfin.2004.03.001

Delcoure, N. (2007). The Determinants of Capital Structure in Transitional Economies.International Review of Economics and Finance, 16, 400-415. https://doi.org/10.1016/j.iref.2005.03.005

Dewenter, K. L., and P. H. Malatesta, 2001, "State-owned and privately-owned firms: An empirical analysis of profitability, leverage, and labor intensity." American Economic Review 91, 320-334. https://doi.org/10.1257/aer.91.1.320

Ezeoha, A. E. (2008). Firm size and corporate financial -leverage choice in a developing economy: Evidence from Nigeria. The Journal of Risk Finance, 9 (4), 351-464. https://doi.org/10.1108/15265940810895016
Fadem, Barbara (2008). High-Yield Behavioral Science (High-Yield Series). Hagerstwon, MD: Lippincott Williams \& Wilkins. ISBN 0-7817-8258-9.

Fama, E. and French, K. (2002), "Testing trade-off and pecking order theory about dividend and debt", Review of Financial Studies, Vol. 15 No. 1, pp. 1-33. https://doi.org/10.1093/rfs/15.1.1

Fosberg, R. (2012). Capital structure and the financial crisis, Journal of Finance \& Accountancy;2012, Vol. 11, p46

Frank Wilcoxon, 1945, "Individual Comparisons by Ranking Methods", Biometrics Bulletin, Vol. 1, No. 6., pp. 80-83. https://doi.org/10.2307/3001968

Frank, Murray Z, and Vidhan K Goyal. 2009. "Capital structure decisions: which factors are reliably important?" Financial Management no. 38 (1):1-37. https://doi.org/10.1111/j.1755-053X.2009.01026.x

Giacomo Morri, Andrea Artegiani, (2015) "The effects of the global financial crisis on the capital structure of EPRA/NAREIT Europe index companies", Journal of European Real Estate Research, Vol. 8 Issue: 1, pp.3-23. https://doi.org/10.1108/JERER-04-2014-0017

Graham, J, (2000), "How Big Are the Tax Benefits of Debt?", The Journal of Finance, 55 (5), pp. 1901 - 1942. https://doi.org/10.1111/0022-1082.00277

Hall, G., Hutchinson, P., \& Michaelas, N. (2004). Determinants of the capital structures of European SMEs Journal of Business Finance \& Accounting, 31, 711-728. https://doi.org/10.1111/j.0306-686X.2004.00554.x

Harris Milton; Raviv Raviv, (1991), the theory of capital structure, The Journal of Finance, Vol. 46, No. 1. (Mar., 1991), pp. 297-355. https://doi.org/10.1111/j.1540-6261.1991.tb03753.x

Hasan M. and Dridi, J. "The effects of the Global Crisis on Islamic Banks and Commercial Banks: A Comparative Study" (2010). International Monetary Fund Working Paper10/201 https://doi.org/10.5089/9781455205318.001

Husam-Aldin N. Al-Malkawi, Rekha Pillai, (2013) "The impact of financial crisis on UAE real estate and construction sector: analysis and implications", Humanomics, Vol. 29 Issue: 2, pp.115-135. https://doi.org/10.1108/08288661311319184

I.V. Larionova, E.I. Meshkova and S.V. Zubkova, 2018, The Capital Requirements (Basel III) and the Banking Sector Business Activity, Journal Review of Global Economics, vol. 7, pp. 527 $-537$. https://doi.org/10.6000/1929-7092.2018.07.49

Idries M. Al-Jarrah, 2010, Competition in the Jordanian's Banking Sector, Dirasat, Administrative Sciences, Volume 37, No. 2.

Imad Z. Ramadan, Qais A. Kilani, Thair A. Kaddumi, 2011, Determinants of Bank Profitability: Evidence from Jordan, International Journal of Academic Research, Vol. 3. No. 4.

Jensen, M. (1986), "Agency costs of free cash flow, corporate finance, and takeovers", American Economic Review, Vol. 76 No. 2, pp. 323-339. https://doi.org/10.1016/0304-405X(76)90026-X

Jensen, M. and Meckling, M. (1976), "Theory of the firm: managerial behavior, agency costs and ownership structure", Journal of Financial Economics, Vol. 3 No. 4, pp. 305-360.

Jian Chen Chunxia Jiang Yujia Lin, (2014),"What determine firms' capital structure in China?", Managerial Finance, Vol. 40 Iss 10 pp. $1024-1039$ https://doi.org/10.1108/MF-06-2013-0163

Jordan, J.; Lowe, J. and Taylor, P., 1998, "Strategy and financial policy in UK small firms", Journal of Business Finance \& Accounting, 25 (1) \& (2), January/March, 1-27. https://doi.org/10.1111/1468-5957.00176

Majluf, Nicholas S. and Stewart C. Myers. "Corporate Financing and Investment Decisions When Firms Have Information That 
Investors Do Not Have," Journal of Financial Economics, Vol. 13, No. 2, 1984, pp. 187-221. https://doi.org/10.1016/0304-405X(84)90023-0

Mann, H. B., \& Whitney, D. R. (1947), "On a test of whether one of 2 random variables is stochastically larger than the other", Annals of Mathematical Statistics, 18, 50-60. https://doi.org/10.1214/aoms/1177730491

Michaelas, N., Chittenden, F., Poutziouris, P. (1999), "Financial Policy and Capital Structure Choice in U.K. SMEs: Empirical Evidence from Company Panel Data", Small Business Economics, Vol. 12 No. 2, pp. 113-130. https://doi.org/10.1023/A:1008010724051

Modigliani, F. and Miller, M. (1958).The Cost of Capital, Corporate Finance and the theory of investment. American Economic Review, 48, 261-97.

Modigliani, F. and Miller, M. (1963). Corporate income taxes and the cost of capital - a correction , American Economic Review , Vol.53 No. 3, pp. 433-443.

Mohammad Alipour, Mir Farhad Seddigh Mohammadi, Hojjatollah Derakhshan, (2015) "Determinants of capital structure: an empirical study of firms in Iran", International Journal of Law and Management, Vol. 57 Issue: 1, pp.53-83. https://doi.org/10.1108/lJLMA-01-2013-0004

Mouamer. Faris M, (2011),"The determinants of capital structure of Palestine-listed companies", The Journal of Risk Finance, Vol. 12 Iss 3 pp. $226-241$ https://doi.org/10.1108/15265941111136969

Myers, S.C. (1977) Determinants of Corporate Borrowing. Journal of Financial Economics, 5, 147-175. https://doi.org/10.1016/0304-405X(77)90015-0

Myers, Stewart C. 1984. "The Capital Structure Puzzle." Journal of Finance. July, 39:3, pp. 575-92. https://doi.org/10.2307/2327916

Myers, Stewart, C. 2001. "Capital Structure." Journal of Economic Perspectives, 15 (2): 81-102. https://doi.org/10.1257/jep.15.2.81

Omet, G. and Nobanee, H. (2001). The Capital Structure of Listed Industrial Companies in Jordan, Arab Journal of Administrative Sciences, 8 (2): 273-289.

Ooi, J. (1999), "The determinants of capital structure: evidence on UK property companies", Journal of Property Investment \& Finance, Vol. 17 No. 5, pp. 46480. https://doi.org/10.1108/14635789910294886

Ozkan, A. 2001. Determinants of Capital Structure and Adjustment to Long Run Target: Evidence from UK Company Panel Data, Journal of Business Finance and Accounting, 28: 175-198. https://doi.org/10.1111/1468-5957.00370

Rajan, R. and Zingales, L. (1995) What Do Know About Capital Structure? Some Evidence from International Data, The Journal of Finance, 50: 1421-1460. https://doi.org/10.1111/j.1540-6261.1995.tb05184.x

Remmers, L., A. Stonehill, R. Wright and T. Beekhuisen (1974). 'Industry and Size as Debt Ratio Determinants in
Manufacturing Internationally', Financial Management (Summer), pp. 24- 32 https://doi.org/10.2307/3665286

Sheikh Nadeem, Wang Zongjun, (2011) "Determinants of capital structure: An empirical study of firms in manufacturing industry of Pakistan", Managerial Finance, Vol. 37 Issue: 2, pp.117-133,

https://doi.org/10.1108/03074351111103668

Siam.W ,Khrawish.H and El-Hammoury.B, (2005). The Capital Structure of Banking Sector in Jordan.Faculty of Economics and Administrative Sciences, Dirasat, Administrative Sciences, Volume 32, No. 1, 2005

Sinan, Akdal, 2011, How Do Firm Characteristics Affect Capital Structure? Some UK Evidence (March 3, 2011). https://doi.org/10.2139/ssrn.1775706

Sufian, F and Noor, M 2009, 'The determinants of Islamic banks' efficiency changes Empirical evidence from the MENA and Asian banking sectors', International Journal of Islamic and Middle Eastern Finance and Management, Vol. 2, No. 2, pp. 120-13. https://doi.org/10.1108/17538390910965149

Syed Ali, S. (2011). Islamic Banking in the Middle-East and NorthAfrica(MENA) Region. Islamic Economic Studies, Vol. 20, No.1, June 2012.

Ternovskaya Helena and Lavrishko Alexander, 2018, The Influence of the Credit Policy of Commercial Banks on the Modernization of the Russian Economy Structure, Journal Review of Global Economics, vol. 7, pp. $433-441$. https://doi.org/10.6000/1929-7092.2018.07.37

Titman, S., and Wessels, R. (1988). The Determinants of Capital Structure Choice. Journal of Finance, 43 (1), pp. 1-19. https://doi.org/10.1111/j.1540-6261.1988.tb02585.x

Ukaegbu , B. and Oino, I, (2014) "The determinants of capital structure: A comparison of financial and non-financial firms in a regulated developing country - Nigeria", African Journal of Economic and Management Studies, Vol. 5 Iss: 3, pp.341 368 https://doi.org/10.1108/AJEMS-11-2012-0072

Wald, John K. 1999. "How Firm Characteristics Affect Capital Structure: An International Comparison." Journal ofFinancia1 Research. Summer, 22:2, pp. 161-87. https://doi.org/10.1111/j.1475-6803.1999.tb00721.x

Wooldridge, Jeffrey M., (2012). Introductory econometrics: a modern approach. Mason, Ohio: South-Western Cengage Learning.

Yu, H. C. (2000). Banks Capital Structure and the Liquid Asset Policy Implication of Taiwan. Pacific Economic Review, 5(1), 109114. https://doi.org/10.1111/1468-0106.00093

Zou, H. and Xiao, Z.J. (2006), "The financing behavior of listed Chinese firms", The British Accounting Review, Vol. 38 No. 3 , pp. 239-58. https://doi.org/10.1016/j.bar.2006.04.008

\section{DOI: https://doi.org/10.6000/1929-7092.2019.08.34}

(C) 2019 Ahmad Y. Khasawneh; Licensee Lifescience Global.

This is an open access article licensed under the terms of the Creative Commons Attribution Non-Commercial License (http://creativecommons.org/licenses/by-nc/3.0/) which permits unrestricted, non-commercial use, distribution and reproduction in any medium, provided the work is properly cited. 